\title{
Genomic Approach to the Assessment of Adverse Effects of Particulate Matters on Skin Cancer and Other Disorders and Underlying Molecular Mechanisms
}

\author{
Nam Gook Kee', Hyun Soo Kim', Hyunjung Choi ${ }^{2}$, Hyoung-June Kim², ${ }^{2}$, Young Rok Seo'* \\ ${ }^{1}$ Department of Life Science, Institute of Environmental Medicine, Dongguk University Biomedi Campus, Goyang, \\ ${ }^{2}$ Bioscience Lab., R\&D Unit, AmorePacific Corporation, Yongin, Korea
}

\begin{abstract}
Air pollutants are in the spotlight because the human body can easily be exposed to them. Among air pollutants, the particulate matter (PM) represents one of the most serious toxicants that can enter the human body through various exposure routes. PMs have various adverse effects and classified as severe carcinogen by International Agency for Research on Cancer. Their physical and chemical characteristics are distinguished by their size. In this review, we summarized the published information on the physicochemical characteristics and adverse effects of PMs on the skin, including carcinogenicity. Through comparisons of biological networks constructed from relationships discussed in the previous scientific publications, we show it is possible to predict skin cancers and other disorders from particle-size-specific signaling alterations of PM-responsive genes. Our review not only helps to grasp the biological association between ambient PMs and skin diseases including cancer, but also provides new approaches to interpret chemical-gene-disease associations regarding the adverse effects of these heterogeneous particles.
\end{abstract}

Key Words Air pollutants, Particulate matter, Skin diseases, Carcinogens, Toxicogenetics

\section{INTRODUCTION}

Studies of air pollution have been spotlighted for decades. Since air quality is highly critical to human life and health, research into air quality has been ongoing to promote living in fresh air conditions [1]. Many researchers have studied diseases that are induced by air pollutants, with focus on identification of related biological reactions in which they are involved. The rate of diseases caused by air pollution has increased every year, and these diseases can occur without distinction between indoor and outdoor pollution [2,3]. Among the airborne pollutants, particulate matter (PM) has been extensively investigated as the major toxic particles. PM is categorized in reference to its diameter $(\mu \mathrm{m}): \mathrm{PM}_{10}$ and $\mathrm{PM}_{2.5}$. Size differences of PM are derived from their sources of origin and are related to their components [4]. Because of these heterogeneous characteristics and their micro-scale size, PMs can expose living things through various routes, provok- ing diverse detrimental effects [5-7].

Investigations on different biological effects caused by different sizes of PMs have mainly focused on the cardiovascular and respiratory diseases [8,9]. The micro-scale size of PM allows for penetration through the skin or vascular system, subsequently leading to adverse effects in the internal organs [10]. Furthermore, recent studies demonstrated the physical damage to the skin caused by particle penetration [11]. Accordingly, the adverse effects on skin resulting from PM exposure has become an important issue, but the underlying mechanistic signaling alterations of PM-induced skin disorders are not fully understood.

The carcinogenic effects of PMs represent a serious toxicological issue. Based on significant cancer incidence and mortality data from epidemiological studies [12,13], pathogenic mechanisms underlying the cancerous effects of PM on the respiratory system are actively being studied using in vivo and in vitro experiments $[14,15]$. Based on sufficient evidence

Received October 11, 2020, Revised October 23, 2020, Accepted October 27, 2020

Correspondence to Young Rok Seo, E-mail: seoyr@dongguk.edu, https://orcid.org/0000-0002-4093-4073

Check for updates Hyoung-June Kim, E-mail: leojune@amorepacific.com, https://orcid.org/0000-0003-0839-1264

*These authors contributed equally to this paper as co-correspondence authors. 
for the cancerous effects of PM, the International Agency for Research on Cancer of the World Health Organization classified PM as a Group 1 carcinogen [16]. However, there is still a lack of knowledge on its carcinogenic effects on skin; an indirect etiological association between skin cancer incidence and carcinogenic PM components, such as black carbon and polycyclic aromatic hydrocarbons (PAHs), has been suggested $[17,18]$, although insufficient experimental details have been reported.

In this review, we summarized the physical and chemical properties of $\mathrm{PM}_{10}$ and $\mathrm{PM}_{2.5}$, and the biological adverse effects on skin. By screening the scientific literature using a text-mining algorithm, we explored the biological relationships between skin disorders and various sized PM in terms of gene-gene and gene-disease networks. This review presents not only the existing knowledge of PM-induced skin disorders, but also supplements the detailed comparative biological association between PM and skin disorders even including cancer with information about the differences between $\mathrm{PM}_{10}$ and $\mathrm{PM}_{2.5}$.

\section{DIFFERENCES IN THE PHYSICAL AND CHEMICAL CHARACTERISTICS OF PM}

On April 14, 2020, the United States Environmental Protection Agency proposed revised National Ambient Air Quality Standards for PMs with different standards for different particle types [19]. They are continuously reviewing and updating the standards about things considered harmful to the public health and the environment. PM shows a wide spectrum of differences depending on their characteristics, especially their size and ambient areas. PM is a mixture of heterogeneous molecules. It forms a mixture of solid particles and liquid droplets consisting of various organic or inorganic particles with various micrometer sizes [20]. This complexity should be considered importantly in identifying its real toxicity and preparing regulatory standards for PM, because there is a lack of sufficient knowledge on the vast differences resulting from variances of particle characteristics as well as chemical or physical interactions among the co-existing multiple molecules.

$\mathrm{PM}_{10}$ has an aerodynamic diameter of less than $10 \mu \mathrm{m}$. Their main components are soil dust, ash, several metal oxides, and biological components (pollen, plant parts, and microorganisms) derived from natural sources. They can float for minutes to hours and can move through the air from 1 to 10 $\mathrm{km}$, and mostly cause allergic or immune responses when inhaled. Silicon, aluminum, potassium, sodium, and calcium are road dust derived from pavement abrasion, and the human body can be exposed to them when they form metal oxides in the $\mathrm{PM}_{10}[21,22]$. Oxide metal ions on the particle surface can lead to forced ion transitions of cell membranes and imbalances of reactive oxygen species (ROS) in the cells [23].

PMs that have a less than $2.5 \mu \mathrm{m}$ of aerodynamic diame- ter are categorized as $\mathrm{PM}_{2.5}$. The main components of $\mathrm{PM}_{2.5}$ are sulfate, nitrate, ammonium, polyaromatic hydrocarbons (PAHs), organic compounds, and several heavy metals, which tend to be generated by industrial activities such as manufacturing processes in factories and solid fuel combustion. It can remain airborne for days to weeks and can widely spread from 100 to $1,000 \mathrm{~km}$, and this means they can easily float in the air for a long period until finally reach human bodies. Micro-sized heavy metals such as copper, antimony, lead, and cadmium are major toxic components of $\mathrm{PM}_{2.5}[21,22]$. They accumulate in human organs and can trigger chronic illnesses; they can easily be inhaled into the respiratory system and come into contact with the skin [24]. Furthermore, the organic components, including PAHs and their oxygenated derivatives, cause mitochondrial malfunction with excessive ROS generation in the cells [25]. Indeed, most of the organic or inorganic components of $\mathrm{PM}_{2.5}$ are derived from chemical reactions and their derivatives [26]. Along with a strong penetrating level of $\mathrm{PM}_{2.5}$ due to their smaller particle size, researchers have suggested that $\mathrm{PM}_{2.5}$ has higher toxicity than $\mathrm{PM}_{10}$ in human organs $[27,28]$.

Diverse epidemiology studies have suggested that PM components and their size distribution are flexible and variable based on regional and seasonal factors [21,29,30]. Zhang et al. [31] collected $\mathrm{PM}_{10}$ and $\mathrm{PM}_{2.5}$ in the Beijing area and conducted a pulmonary toxicity study using Wister rats. They confirmed the differences in components distribution between $\mathrm{PM}_{10}$ and $\mathrm{PM}_{2.5}$ through element analysis, and the Wister rats treated with PMs demonstrated increased levels of inflammation biomarkers including interleukin (IL)-1, IL-6, and $\mathrm{TNF}-\alpha$, and also increased DNA damage in lung cells. Experimental studies using human bronchial epithelial cells reported seasonal differences in PM components, and different particle sizes were significantly related to different changes in the expression of lung cancer marker proteins [32-34]: KRAS oncoprotein, PTEN, and tumor suppressor p53 (TP53) showed dose- and time-dependent activation under chronic $\mathrm{PM}_{2.5}$ exposure [35].

The above knowledge revealed the importance of considering each characteristic of $\mathrm{PM}_{10}$ and $\mathrm{PM}_{2.5}$ in studying their adverse effects. Evidence of the different biological activity of $\mathrm{PM}_{10}$ and $\mathrm{PM}_{2.5}$ has already been discussed [36]; accordingly, comparisons between particle types of PM are actively being made by in vitro and in vivo studies. In most cases of respiratory system-based experimental studies, $\mathrm{PM}_{2.5}$ is responsible for PM-induced oxidative stress, DNA damage, and excessive activation of inflammatory mediators [37-39]. The carcinogenic risk of $P M$ is also variable depending on the particle size. Compared with $\mathrm{PM}_{10}, \mathrm{PM}_{2.5}$ is generally considered to confer a higher risk of respiratory cancer because of the smaller particle size, which can, therefore, more easily penetrate tissue $[12,35,40]$. However, compared with the knowledge on respiratory toxicity, a complete understanding of the adverse dermatological effects of PM is still lacking, 
even though skin is also frequently in contact with ambient pollutants, possibly even more so than the respiratory tract.

\section{THE ADVERSE EFFECTS OF PIM ON SKIN}

In recent years, detrimental health effects caused by PM exposure have become a serious worldwide issue. Through numerous approaches, researchers and government officers demonstrated adverse effects caused by PMs and utilized this information for establishing regulatory standards, and proposed the toxicity reports of their health risk [41]. The strong association between PM exposure and adverse health effects was established by showing the accumulated damage of various cells and tissues in human organs, especially the respiratory and cardiovascular systems [42-44]. However, skin toxicity and carcinogenicity due to ambient PM have been less understood than the respiratory system response.

Skin comprises the largest surface area of the human body and it functions as a barrier for protection from the external environment. Frequent contact with extrinsic harmful substances stimulates the defense systems of the skin, including dynamic responses of the immune system. These effects occurring in the epidermis, dermis, and deeper subcutaneous layer have been studied as the first-line physical response caused by contact with toxicants via skin absorption [45]. Biological effects of particles in multilayer structures are dependent on their ability to penetrate through tissue layers, and this knowledge is important to interpret how the differences in particle characteristics of PM contribute to their different harmful effects and their ability to disrupt cell signal functions [46].

Although the particle type distribution and the concentration of PM vary depending on the weather and location, phenomenological associations between the increase in levels of airborne PMs and the diagnosis frequency of skin diseases have been commonly reported in epidemiological studies. Exposure to PM, which results in increased oxidative stress and pro-inflammatory cytokines, is known to cause common inflammatory skin disorders, such as atopic dermatitis, acne, and psoriasis [47-49]. Despite geological and seasonal differences among the countries involved in the research, statistical associations between PM exposure and skin disorders are commonly reported for $\mathrm{PM}_{10}$ and $\mathrm{PM}_{2.5}$ [50] and are difficult to discuss separately. Epidemiologic study has provided a comprehensive scope of the associations between PM and skin diseases based on statistical interpretations, but it is hard to demonstrate a link between pollution-mediated skin damage and specific characteristics of the ambient PM fraction.

PM-mediated adverse effects on skin have also been assessed in in vivo and in vitro studies. Electron microscopy analysis showed that PMs were able to penetrate the skin tissue [10], and the apoptotic process appeared in the reconstructed human epidermis model in response to treatment with PM [51]. Also, PMs treated to porcine skin had a detrimental effect on the skin barriers, allowing greater amounts of test substances to permeate the skin sample [52]. The micro-size PMs penetrate the skin, breaking down the skin barrier and causing a cutaneous inflammatory response, which results in various skin disorders [11]. Several studies using human keratinocytes (HaCaT) found excessive inflammation, oxidative stress, and apoptosis in cells exposed to $\mathrm{PM}_{10}$ and $\mathrm{PM}_{2.5}$, which may drive keratinocyte dysfunction [53,54]. In a human epidermis mimicry model study, $\mathrm{PM}_{2.5}$ penetration caused skin damage with ROS production and NF-кB-mediated inflammatory responses [51]. Based on the above findings, ROS-mediated inflammatory responses are thought to be major reasons for PM-induced skin damage, but the evidence is still insufficient to demonstrate the underlying mechanisms and, moreover, the differences between the effects of $\mathrm{PM}_{2.5}$ and $\mathrm{PM}_{10}$ are unclear.

The risk of skin cancer from PM exposure is also not fully understood. Approximate correlations between increased ambient concentrations of PM and diagnoses of skin cancer have been observed in epidemiological studies, but opinions are inconsistent on whether $\mathrm{PM}_{10}$ or $\mathrm{PM}_{2.5}$ is more carcinogenic. Although there are no clear significant associations between $\mathrm{PM}_{10}$ and skin cancer incidences in epidemiological studies, several indirect inferences have been suggested from in vitro studies evaluating $\mathrm{PM}_{10}$-induced cytotoxicity in human dermal fibroblasts, including accumulated autophagy and proinflammatory effects [55]. According to several cohort studies, there is a positive correlation between urban $\mathrm{PM}_{2.5}$ exposure and the incidence of skin cancers, including melanoma $[11,56,57]$. A study using $\mathrm{HaCaT}$ cells also reported a risk of cancer from $\mathrm{PM}_{2.5}$ exposure with increasing apoptosis and interleukin-mediated inflammatory responses [58]. Despite the efforts described above, research on PM-induced skin carcinogenicity has produced fragmentary descriptions of the mechanisms involved compared with studies on the respiratory system. Almost all risk factors are based on the cancerous effects of the hazardous components of $\mathrm{PM}_{2.5}$, including black carbon and PAHs [59,60], or on the stimulation of cytotoxic signals that leads to carcinogenesis. Severe levels of ROS production and pro-inflammatory cytokine secretion are actively discussed as major promoters of skin cancer $[61,62]$, and have been demonstrated to occur upon PM exposure in other experimental studies. However, the studies neither cover the oncological aspects nor distinguish between the numerous species of skin cancer, which makes it difficult to clarify any differences between $\mathrm{PM}_{10}$ and $\mathrm{PM}_{2.5}$.

To overcome the above limitations in the interpretation of differences between the adverse effects of $\mathrm{PM}_{10}$ and $\mathrm{PM}_{2.5}$ on skin, we utilized a new approach using transcriptomic profiles related to PM. By screening relationships among the PM-responsive gene lists based on the literature information, we reviewed the predicted biological alterations of skin by PM. As the physical and chemical properties of PMs vary with size, 
comparing $\mathrm{PM}_{10}$ and $\mathrm{PM}_{2.5}$ may provide helpful information on how each size of PM contributes to adverse skin effects, including cancer.

\section{COMPARISON OF $\mathrm{PM}_{10} \& \mathrm{PI}_{2.5}$ IN TERIMS OF BIOLOGICAL PATHWAY ALTERATIONS}

Although diverse studies have focused on the adverse effects of PM in skin at a visible level, relevant interactions among biomolecules and the subsequent alterations of biological pathways are not clearly understood. In the present study, we suggest differences of $\mathrm{PM}_{10}$ and $\mathrm{PM}_{2.5}$ in their contribution to pathogenesis of skin cancers and other disorders, in terms of the biological networks among genomic data, according to information in the scientific literature. Our approach allows for interpreting the alteration of various cellular processes of diseases in response to certain experimental changes.

We collected a set of genes associated with $\mathrm{PM}_{10}$ and $\mathrm{PM}_{2.5}$ from studies that identified the alterations of gene expression after exposure to a particular PM. The overlapping genes of $\mathrm{PM}_{10}$ and $\mathrm{PM}_{2.5}$ were excluded from the network configuration to compare the differences. The gene subsets of each PM size-relevant gene set were separately used to create molecular signaling networks. Literature-based software Pathway Studio web 12.3.0.16 (Elsevier) was utilized to present the biological networks among the identified genes. Pathway studio is a text-mining based pathway analysis software that contains a curated database with their own text-mining module. Pathway Studio navigates biological information such as information about of genetic interactions, cellular processes, and diseases referring to relevant sentences from the literature databases.

We used $\mathrm{PM}_{10}$ associated 200 genes and $\mathrm{PM}_{2.5}$ associated 696 genes to explore the networks related to the skin system from PM exposure along with cellular process and disease information. We found biological information on association between genes, cellular processes, and diseases by the curated network analysis results based on the number of references $\geq 10$. According to the constructed network of $\mathrm{PM}_{10}$ associated genes in terms of the skin system, 41 genes known as skin disease-related, including TP53 and VEGFA, were used to construct a network among the genegene interactions, diseases, and cellular processes (Fig. 1A) [63-65]. In the $\mathrm{PM}_{2.5}$ related molecular signaling network, the biological network of skin system-related 53 genes, including EGF receptor (EGFR) and jun proto-oncogene (JUN), known as skin disease- and cancer-related genes, was constructed (Fig. 1B) [66-68]. These genes are the main components that make up the network, highlighting skin diseases that can occur due to changes in expression during skin exposure to PMs. It was associated with cellular processes such as 'epithelization' and 're-epithelialization' in skin, which means that expression changes of related genes may weaken the protection and recovery function of the skin in both networks
$[69,70]$. In addition, the biological network among PM-related genes showed associations with alteration of the skin barrier and morphological structures [52,71,72]. These networks also provide predicted diseases from the PM-related genes. Among diseases predicted by the molecular signaling networks, 'dermatitis', 'psoriasis', and several skin cancers have been shown to be important diseases in both the $\mathrm{PM}_{10}$ and $\mathrm{PM}_{2.5}$ associated genetic networks (Fig. 1) [73,74].

To interpret the potential comprehensive key networks and to clarify differences between $\mathrm{PM}_{10}$ and $\mathrm{PM}_{2.5}$, we selected the major elements considered as the centrality of the network components from the analyzed pathways of $\mathrm{PM}_{10}$ and $\mathrm{PM}_{2.5}$. By sorting the major regulators in Figure 1 using the classified network components, we constructed their hub pathways (Fig. 2). According to the PM-related hub pathways reconstructed using key regulators, the $\mathrm{PM}_{10}$ specific molecular signaling network was identified from the information of interactions among key genes, such as TP53, VEGFA, fibronectin 1 , colony stimulating factor 2 , and peroxisome proliferator activated receptor gamma, cellular process and disease. We found a correlation between the TP53 gene and skin pigmentation in the network of $\mathrm{PM}_{10}$. Box and Terzian [75] mentioned the role of TP53 in skin pigmentation. In the $\mathrm{PM}_{2.5}$ specific molecular signaling network, the information of biological interactions among EGFR, JUN, fibroblast growth factor 2, CC motif chemokine ligand 2, and the intercellular adhesion molecule 1 (ICAM1) gene were identified. We could find an association between the 5 key regulators and the various skin diseases and skin cancer in numerous studies $[66,76,77]$. We also found a correlation between ICAM1 and skin barrier function and dermatitis. Matsunaga et al. [78] mentioned that the expression of ICAM1 was associated with epidermal barrier function, and that the expression of ICAM1 was not checked in atopic dermatitis. Figure 3 shows final summary of main genes, cellular processes, and diseases into the hub pathway from Figure 2. It provided a scheme to find out how the adverse effects on the skin differ by the size of the naturally occurring $\mathrm{PM}_{10}$ and the artificially occurring $\mathrm{PM}_{2.5}$ in the air.

Diverse studies on the respiratory system show that $\mathrm{PM}_{2.5}$ has stronger carcinogenic effects than $\mathrm{PM}_{10}$. However, our skin-focused screening suggests that $\mathrm{PM}_{10}$, as well as $\mathrm{PM}_{2.5}$, significantly correlates with several skin cancers. As we reviewed in a previous section, the cancerous effects and detailed mechanisms of PM toxicity on skin are poorly understood compared with the effects on the respiratory system. Further validation is required to clarify whether the biological associations predicted in this review are specific to the skin or are due to bias by the data screening algorithm. In fact, our network-based literature review is based on relationships mentioned in the existing scientific literature. Therefore, experimental mechanism studies will be required to verify our findings, which indicate differences between the $\mathrm{PM}_{10}$ and $\mathrm{PM}_{2.5}$-induced alterations of intracellular signaling pathways 
A

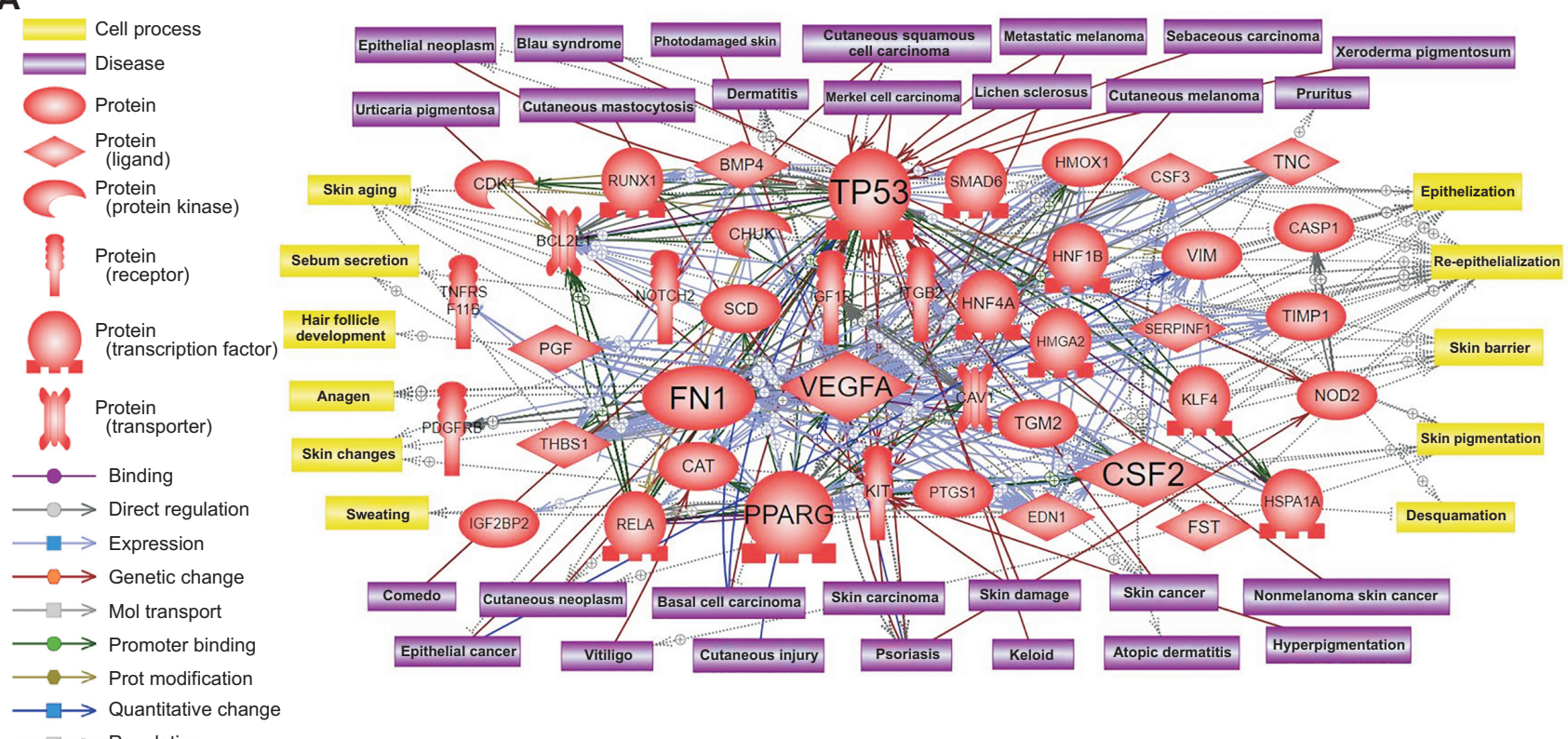

B

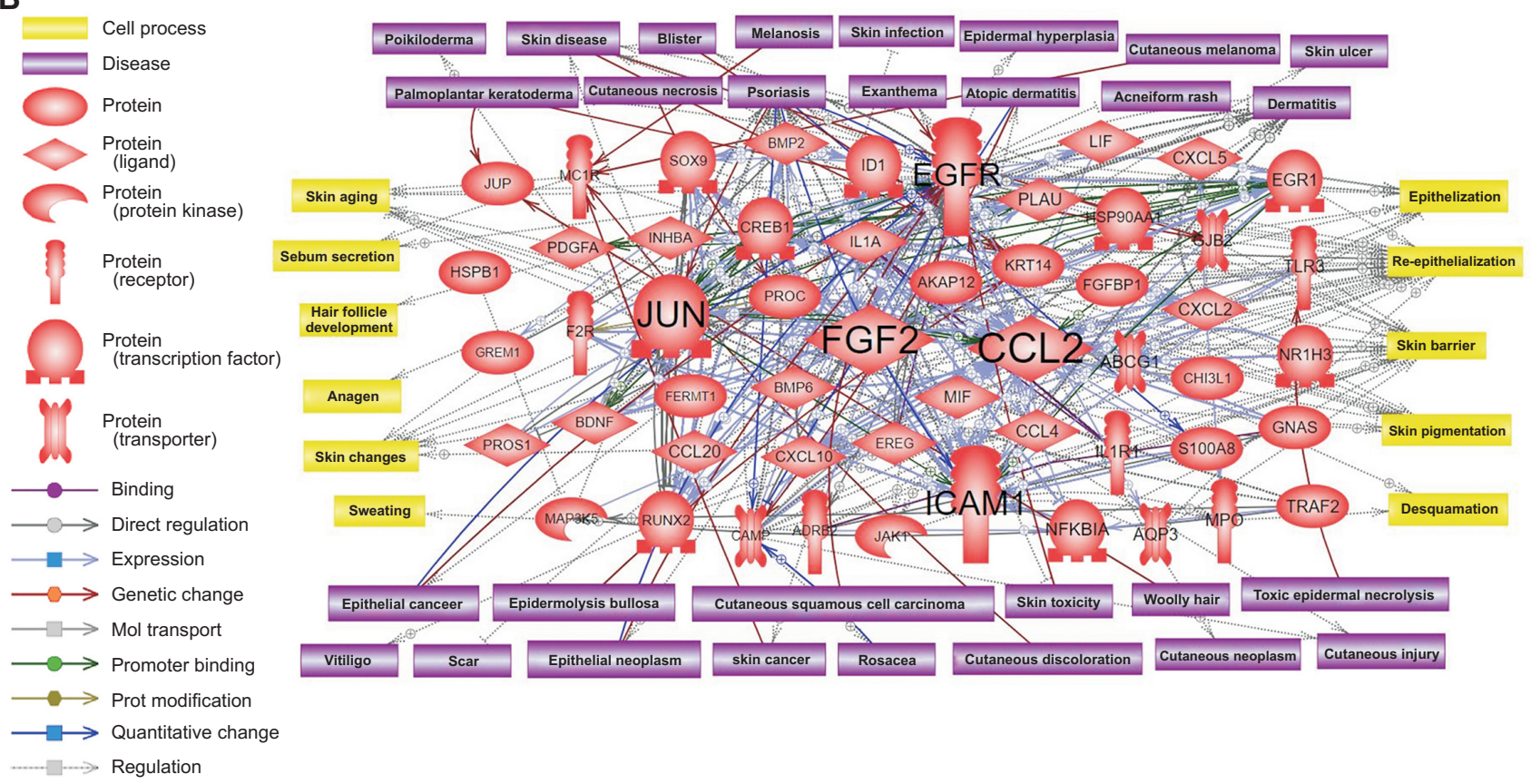

Figure 1. Potential biological signaling networks related to $\mathrm{PM}_{10} \& \mathrm{PM}_{2.5}$ exposure inducing skin-related cellular processes and diseases. Molecular signaling network results using collected PM associated genes. Pathway Studio software was utilized to analyze the biological signaling networks. (A) Analysis of the $\mathrm{PM}_{10}$ related genes, and (B) analysis of the $\mathrm{PM}_{2.5}$ related genes for understanding how the biological reaction from exposure to $\mathrm{PM}_{10}$ \& $\mathrm{PM}_{2.5}$ affects related cellular processes and diseases. Large-sized entities indicate key genes in the networks regarding their connectivity with the surrounding entities. Schematic legends are located on the left side of each pathway. CDK, cyclin-dependent kinase; TNFRS, TNF receptors; PDGFR, platelet-derived growth factor receptors; PGF, placental growth factor; IGF, insulin like growth factor 1; THBS1, thrombospondin 1; PPARG, peroxisome proliferator activated receptor gamma; FN1, fibronectin 1; CSF2, colony stimulating factor 2; JUN, jun protooncogene; FGF2, fibroblast growth factor 2; CCL2, CC motif chemokine ligand 2; ICAM1, intercellular adhesion molecule 1. 


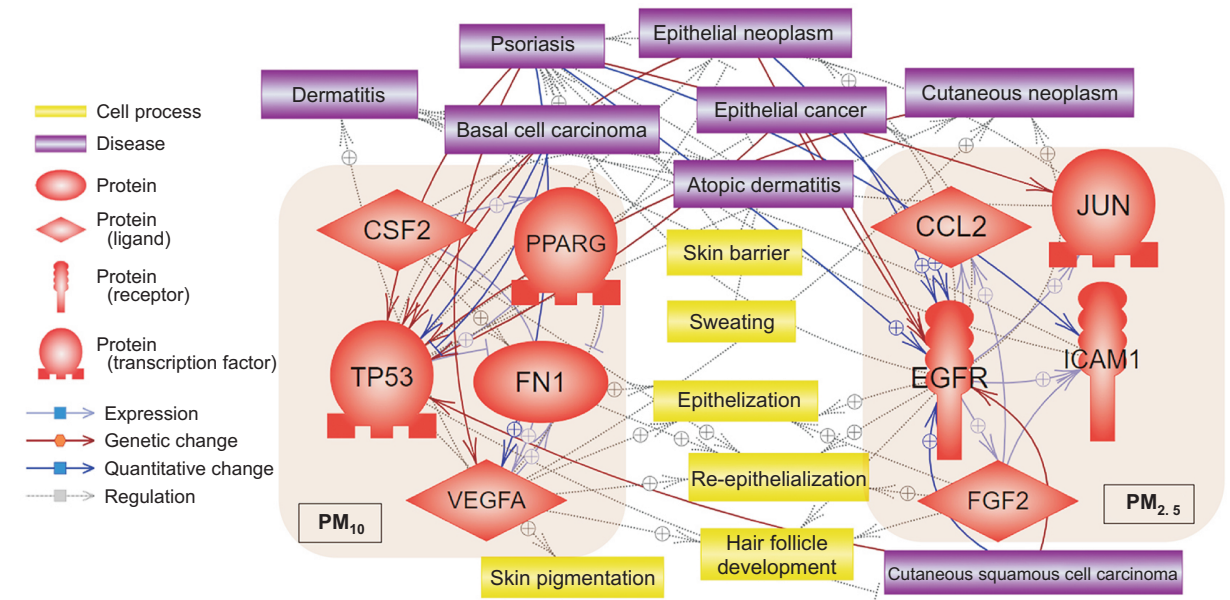

Figure 2. Hub potential biological signaling network with key regulators and related signaling pathways. Key regulators with expression changes due to $\mathrm{PM}_{10}$ \& $\mathrm{PM}_{2.5}$ exposure and associated molecular signaling networks have biological effects related to each size, while the same effects differ in related genes. CSF2, colony stimulating factor 2; TP53, tumor protein p53; PPARG, peroxisome proliferator activated receptor gamma; FN1, fibronectin 1; CCL2, CC motif chemokine ligand 2; EGFR, EGF receptor; FGF2, fibroblast growth factor 2; JUN, jun proto-oncogene; ICAM1, intercellular adhesion molecule 1; VEGFA, vascular endothelial growth factor A.

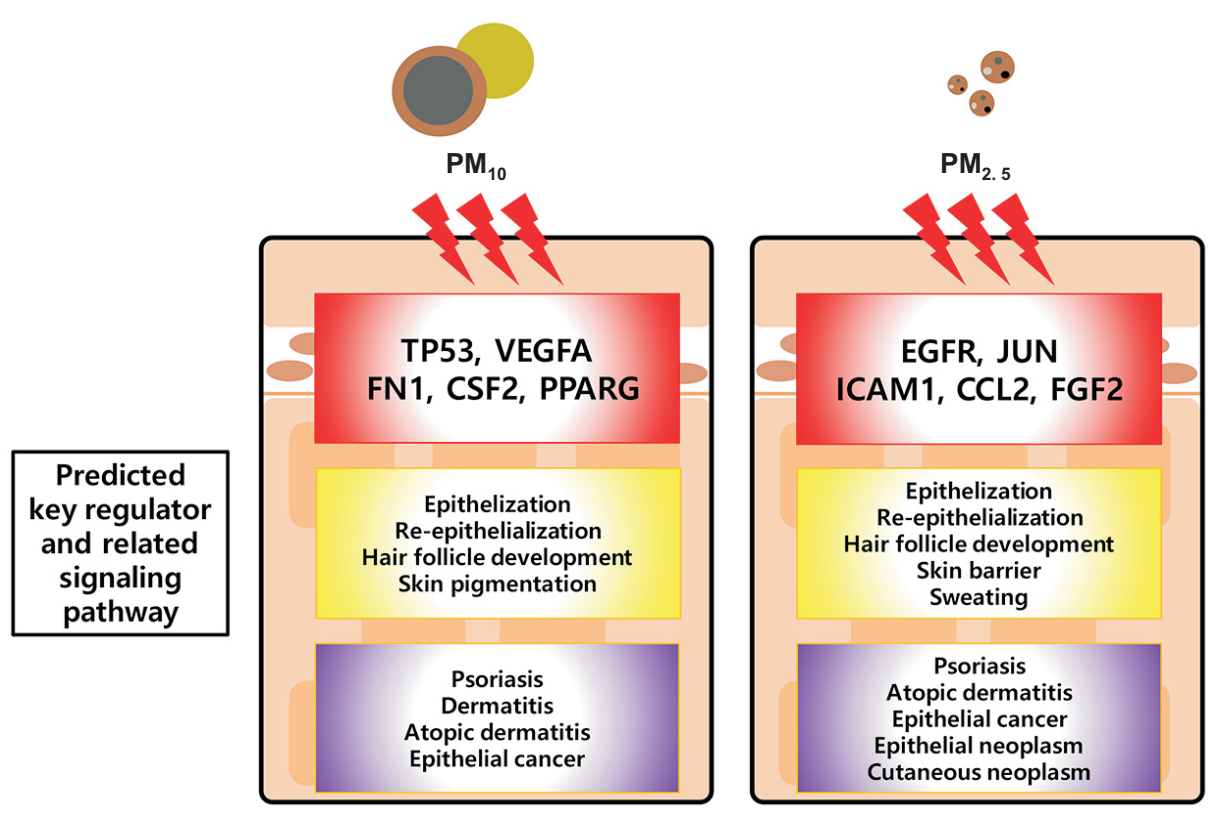

Figure 3. Summary of effects of $\mathrm{PM}_{10}$ and $\mathrm{PM}_{2.5}$ exposure on skin. The scheme illustrates the associated biological signaling pathways followed by expression changes of the key regulators expected during skin exposure to $\mathrm{PM}_{10}$ \& $\mathrm{PM}_{2.5}$. This model provides the potential biological mechanisms differentiated by exposure and size of PMs. TP53, tumor protein p53; FN1, fibronectin 1; CSF2, colony stimulating factor 2; PPARG, peroxisome proliferator activated receptor gamma; EGFR, EGF receptor; JUN, jun proto-oncogene; ICAM1, intercellular adhesion molecule 1; CCL2, CC motif chemokine ligand 2; FGF2, fibroblast growth factor 2; VEGFA, vascular endothelial growth factor $A$.

that lead to adverse effects on the skin.

\section{CONCLUSION}

PMs are composed of micro-sized heterogeneous particles that have various organic and inorganic components. Harmful effects derived from human PM exposure is a worldwide issue, but the mechanisms underlying its skin toxicity remain unclear, especially in relation to the PM size. Here, we introduced the characteristics of PM, discussed their adverse effects on skin, and attempted to compare the underlying signaling alterations by $\mathrm{PM}_{10}$ and $\mathrm{PM}_{2.5}$ associated with skin can- cer and other disorders. Although the related gene lists are different, the predicted cellular processes and diseases from gene-gene interaction were similar in each PM size. A significant relationship with skin cancer was predicted for both the $\mathrm{PM}_{10}$ - and $\mathrm{PM}_{2.5}$-related pathways. Further validation studies will be required to demonstrate the exact pathway, but our review with simple genomic approaches can help clarify the skin-related biological alterations caused by PM exposure, as well as provide evidence for a genomic-based outline to screen for the biological relationships between chemicals and diseases. 


\section{ACKNOWLEDGMENTS}

This work was supported by a grant from the Amorepacific Corporation R\&D center.

\section{CONFLICTS OF INTEREST}

No potential conflicts of interest were disclosed.

\section{ORCID}

Nam Gook Kee, https://orcid.org/0000-0002-0760-7804 Hyun Soo Kim, https://orcid.org/0000-0001-7805-4429 Hyunjung Choi, https://orcid.org/0000-0003-4435-2801 Hyoung-June Kim, https://orcid.org/0000-0003-0839-1264 Young Rok Seo, https://orcid.org/0000-0002-4093-4073

\section{REFERENCES}

1. World Health Organization. Ambient (outdoor) air pollution. https://www.who.int/news-room/fact-sheets/detail/ambient(outdoor)-air-quality-and-health. Accessed September 23, 2020.

2. Wallace L. Indoor sources of ultrafine and accumulation mode particles: size distributions, size-resolved concentrations, and source strengths. Aerosol Sci Technol 2006;40:348-60.

3. Leung DYC. Outdoor-indoor air pollution in urban environment: challenges and opportunity. Front Environ Sci 2015;2:69.

4. Davidson $\mathrm{Cl}$, Phalen RF, Solomon PA. Airborne particulate matter and human health: a review. Aerosol Sci Technol 2005;39:737-49.

5. Sarigiannis DA, Karakitsios SP, Zikopoulos D, Nikolaki S, Kermenidou M. Lung cancer risk from PAHs emitted from biomass combustion. Environ Res 2015;137:147-56.

6. Esposito V, Lucariello A, Savarese L, Cinelli MP, Ferraraccio F, Bianco A, et al. Morphology changes in human lung epithelial cells after exposure to diesel exhaust micron sub particles $\left(\mathrm{PM}_{1.0}\right)$ and pollen allergens. Environ Pollut 2012;171:162-7.

7. Oberdörster G. Pulmonary effects of inhaled ultrafine particles. Int Arch Occup Environ Health 2001;74:1-8.

8. Schulz H, Harder V, Ibald-Mulli A, Khandoga A, Koenig W, Krombach $F$, et al. Cardiovascular effects of fine and ultrafine particles. J Aerosol Med 2005;18:1-22.

9. Ristovski ZD, Miljevic B, Surawski NC, Morawska L, Fong KM, Goh F, et al. Respiratory health effects of diesel particulate matter. Respirology 2012;17:201-12.

10. Jin SP, Li Z, Choi EK, Lee S, Kim YK, Seo EY, et al. Urban particulate matter in air pollution penetrates into the barrierdisrupted skin and produces ROS-dependent cutaneous inflammatory response in vivo [published online ahead of print April 30, 2018]. J Dermatol Sci. doi: 10.1016/j.jdermsci. 2018.04.015.

11. Kim KE, Cho D, Park HJ. Air pollution and skin diseases: adverse effects of airborne particulate matter on various skin diseases. Life Sci 2016;152:126-34.
12. Li R, Zhou R, Zhang J. Function of $\mathrm{PM}_{2.5}$ in the pathogenesis of lung cancer and chronic airway inflammatory diseases. Oncol Lett 2018;15:7506-14.

13. Raaschou-Nielsen O, Andersen ZJ, Beelen R, Samoli E, Stafoggia M, Weinmayr G, et al. Air pollution and lung cancer incidence in 17 European cohorts: prospective analyses from the European Study of Cohorts for Air Pollution Effects (ESCAPE). Lancet Oncol 2013;14:813-22.

14. Liu C, Guo H, Cheng X, Shao M, Wu C, Wang S, et al. Exposure to airborne PM2.5 suppresses microRNA expression and deregulates target oncogenes that cause neoplastic transformation in NIH3T3 cells. Oncotarget 2015;6:29428-39.

15. Li X, Lv Y, Gao N, Sun H, Lu R, Yang H, et al. microRNA-802/ Rnd3 pathway imposes on carcinogenesis and metastasis of fine particulate matter exposure. Oncotarget 2016;7:35026-43.

16. Pershagen G. Air pollution and cancer. IARC Sci Publ 1990;(104):240-51.

17. Bauer A. [Skin cancer as occupational disease]. Hautarzt 2016;67:884-90. German.

18. Puri P, Nandar SK, Kathuria S, Ramesh V. Effects of air pollution on the skin: a review. Indian J Dermatol Venereol Leprol 2017;83:415-23.

19. US EPA. 40 CFR Part 50. National Ambient Air Quality Standards for particulate matter. Final Rule. Fed Regist 1997;62:3865138760.

20. Ciencewicki J, Jaspers I. Air pollution and respiratory viral infection. Inhal Toxicol 2007;19:1135-46.

21. Kim KH, Kabir E, Kabir S. A review on the human health impact of airborne particulate matter. Environ Int 2015;74:136-43.

22. Cheung K, Daher N, Kam W, Shafer MM, Ning Z, Schauer JJ, et al. Spatial and temporal variation of chemical composition and mass closure of ambient coarse particulate matter $\left(\mathrm{PM}_{10-2.5}\right)$ in the Los Angeles area. Atmos Environ 2011;45:2651-62.

23. Karlsson HL, Gustafsson J, Cronholm P, Möller L. Sizedependent toxicity of metal oxide particles--a comparison between nano- and micrometer size. Toxicol Lett 2009;188:1128.

24. Zhao H, Xia B, Fan C, Zhao P, Shen S. Human health risk from soil heavy metal contamination under different land uses near Dabaoshan Mine, Southern China. Sci Total Environ 2012;417418:45-54.

25. Li N, Sioutas C, Cho A, Schmitz D, Misra C, Sempf J, et al. Ultrafine particulate pollutants induce oxidative stress and mitochondrial damage. Environ Health Perspect 2003;111:45560.

26. Srimuruganandam B, Shiva Nagendra SM. Source characterization of PM10 and PM2.5 mass using a chemical mass balance model at urban roadside. Sci Total Environ 2012;433:8-19.

27. Kim W, Jeong SC, Shin C, Song MK, Cho Y, Lim J, et al. A study of cytotoxicity and genotoxicity of particulate matter $\left(\mathrm{PM}_{2.5}\right)$ in human lung epithelial cells (A549). Mol Cell Toxicol 2018;14:16372.

28. Jeong SC, Shin CY, Song MK, Cho Y, Ryu JC. Gene expression 
Kee et al.

profiling of human alveolar epithelial cells (A549 cells) exposed to atmospheric particulate matter $2.5\left(\mathrm{PM}_{2.5}\right)$ collected from Seoul, Korea. Mol Cell Toxicol 2014;10:361-8.

29. Tian YZ, Shi GL, Huang-Fu YQ, Song DL, Liu JY, Zhou LD, et al. Seasonal and regional variations of source contributions for PM10 and PM2.5 in urban environment. Sci Total Environ 2016;557-558:697-704.

30. Fruin S, Urman R, Lurmann F, McConnell R, Gauderman $\mathrm{J}$, Rappaport E, et al. Spatial variation in particulate matter components over a large urban area. Atmos Environ 2014;83:211-9.

31. Zhang W, Lei T, Lin ZQ, Zhang HS, Yang DF, Xi ZG, et al. Pulmonary toxicity study in rats with $\mathrm{PM}_{10}$ and $\mathrm{PM}_{2.5}$ : differential responses related to scale and composition. Atmos Environ 2011;45:1034-41.

32. Ferrer I, Zugazagoitia J, Herbertz S, John W, Paz-Ares L, Schmid-Bindert G. KRAS-Mutant non-small cell lung cancer: from biology to therapy. Lung Cancer 2018;124:53-64.

33. Forgacs E, Biesterveld EJ, Sekido Y, Fong K, Muneer S, Wistuba II, et al. Mutation analysis of the PTEN/MMAC1 gene in lung cancer. Oncogene 1998;17:1557-65.

34. Iggo R, Gatter K, Bartek J, Lane D, Harris AL. Increased expression of mutant forms of p53 oncogene in primary lung cancer. Lancet 1990;335:675-9.

35. Chen S, Li D, Zhang H, Yu D, Chen R, Zhang B, et al. The development of a cell-based model for the assessment of carcinogenic potential upon long-term PM2.5 exposure. Environ Int 2019;131:104943.

36. Diociaiuti M, Balduzzi M, De Berardis B, Cattani G, Stacchini G, Ziemacki G, et al. The two PM(2.5) (fine) and PM(2.5-10) (coarse) fractions: evidence of different biological activity. Environ Res 2001;86:254-62.

37. Choi JH, Kim JS, Kim YC, Kim YS, Chung NH, Cho MH. Comparative study of PM2.5 - and PM10 - induced oxidative stress in rat lung epithelial cells. J Vet Sci 2004;5:11-8.

38. Yang J, Chen $\mathrm{Y}, \mathrm{Yu} Z$, Ding $\mathrm{H}$, Ma Z. The influence of $\mathrm{PM}_{25}$ on lung injury and cytokines in mice. Exp Ther Med 2019;18:250311.

39. Pozzi R, De Berardis B, Paoletti L, Guastadisegni C. Inflammatory mediators induced by coarse (PM2.5-10) and fine (PM2.5) urban air particles in RAW 264.7 cells. Toxicology 2003;183:243-54.

40. Yang B, Xiao C. PM2.5 exposure significantly improves the exacerbation of A549 tumor-bearing CB17-SCID mice. Environ Toxicol Pharmacol 2018;60:169-75.

41. World Health Organization. Ambient air pollution: a global assessment of exposure and burden of disease. Geneva, World Health Organization, 2016.

42. Dockery DW, Pope CA 3rd, Xu X, Spengler JD, Ware JH, Fay $\mathrm{ME}$, et al. An association between air pollution and mortality in six U.S. cities. N Engl J Med 1993;329:1753-9.

43. Jia $Y Y$, Wang $Q$, Liu T. Toxicity research of $\mathrm{PM}_{2.5}$ compositions in vitro. Int J Environ Res Public Health 2017;14:232.

44. Pope CA 3rd, Bates DV, Raizenne ME. Health effects of particulate air pollution: time for reassessment? Environ Health Perspect 1995;103:472-80.

45. Nguyen AV, Soulika AM. The dynamics of the skin's immune system. Int J Mol Sci 2019;20:1811.

46. Park M, Joo HS, Lee K, Jang M, Kim SD, Kim I, et al. Differential toxicities of fine particulate matters from various sources. Sci Rep 2018;8:17007.

47. Song S, Lee K, Lee YM, Lee JH, Lee SI, Yu SD, et al. Acute health effects of urban fine and ultrafine particles on children with atopic dermatitis. Environ Res 2011;111:394-9.

48. Morgenstern V, Zutavern A, Cyrys J, Brockow I, Koletzko S, Krämer $U$, et al. Atopic diseases, allergic sensitization, and exposure to traffic-related air pollution in children. Am J Respir Crit Care Med 2008;177:1331-7.

49. Annesi-Maesano I, Moreau D, Caillaud D, Lavaud F, Le Moullec $\mathrm{Y}$, Taytard A, et al. Residential proximity fine particles related to allergic sensitisation and asthma in primary school children. Respir Med 2007;101:1721-9.

50. Ngoc LTN, Park D, Lee Y, Lee YC. Systematic review and metaanalysis of human skin diseases due to particulate matter. Int J Environ Res Public Health 2017;14:1458.

51. Magnani ND, Muresan XM, Belmonte G, Cervellati F, Sticozzi C, Pecorelli A, et al. Skin damage mechanisms related to airborne particulate matter exposure. Toxicol Sci 2016;149:227-36.

52. Pan TL, Wang PW, Aljuffali IA, Huang CT, Lee CW, Fang JY. The impact of urban particulate pollution on skin barrier function and the subsequent drug absorption. J Dermatol Sci 2015;78:51-60.

53. Lin ZC, Lee CW, Tsai MH, Ko HH, Fang JY, Chiang YC, et al. Eupafolin nanoparticles protect $\mathrm{HaCaT}$ keratinocytes from particulate matter-induced inflammation and oxidative stress. Int J Nanomedicine 2016;11:3907-26

54. Piao MJ, Ahn MJ, Kang KA, Ryu YS, Hyun YJ, Shilnikova K, et al. Particulate matter 2.5 damages skin cells by inducing oxidative stress, subcellular organelle dysfunction, and apoptosis. Arch Toxicol 2018;92:2077-91.

55. Park SY, Byun EJ, Lee JD, Kim S, Kim HS. Air pollution, autophagy, and skin aging: impact of particulate matter $\left(\mathrm{PM}_{10}\right)$ on human dermal fibroblasts. Int J Mol Sci 2018;19:2727.

56. Avogbe PH, Ayi-Fanou L, Autrup H, Loft S, Fayomi B, Sanni A, et al. Ultrafine particulate matter and high-level benzene urban air pollution in relation to oxidative DNA damage. Carcinogenesis 2005;26:613-20.

57. Liu J, Chen Y, Cao H, Zhang A. Burden of typical diseases attributed to the sources of $\mathrm{PM}_{2.5}$-bound toxic metals in Beijing: an integrated approach to source apportionment and QALYs. Environ Int 2019;131:105041.

58. Zhang Y, Zheng L, Tuo J, Liu Q, Zhang X, Xu Z, et al. Analysis of $\mathrm{PM}_{2.5}$-induced cytotoxicity in human $\mathrm{HaCaT}$ cells based on a microfluidic system. Toxicol In Vitro 2017;43:1-8.

59. Gorgizadeh M, Azarpira N, Dehdari Veis R, Sattarahmady $\mathrm{N}$. Repression of melanoma tumor in vitro and in vivo by photothermal effect of carbon xerogel nanoparticles. Colloids Surf B Biointerfaces 2019;176:449-55.

60. Haigh PI, Lucci A, Turner RR, Bostick PJ, Krasne DL, Stern SL, 
et al. Carbon dye histologically confirms the identity of sentinel lymph nodes in cutaneous melanoma. Cancer 2001;92:535-41.

61. F'guyer S, Afaq F, Mukhtar H. Photochemoprevention of skin cancer by botanical agents. Photodermatol Photoimmunol Photomed 2003;19:56-72.

62. Godic A, Poljšak B, Adamic M, Dahmane R. The role of antioxidants in skin cancer prevention and treatment. Oxid Med Cell Longev 2014;2014:860479.

63. Giglia-Mari G, Sarasin A. TP53 mutations in human skin cancers. Hum Mutat 2003;21:217-28.

64. Kunstfeld R, Hirakawa S, Hong YK, Schacht V, LangeAsschenfeldt B, Velasco P, et al. Induction of cutaneous delayedtype hypersensitivity reactions in VEGF-A transgenic mice results in chronic skin inflammation associated with persistent lymphatic hyperplasia. Blood 2004;104:1048-57.

65. Huggenberger R, Ullmann S, Proulx ST, Pytowski B, Alitalo K, Detmar M. Stimulation of lymphangiogenesis via VEGFR-3 inhibits chronic skin inflammation. J Exp Med 2010;207:2255-69.

66. Cheng X, Jin J, Hu L, Shen D, Dong XP, Samie MA, et al. TRP channel regulates EGFR signaling in hair morphogenesis and skin barrier formation. Cell 2010;141:331-43.

67. Zenz R, Eferl R, Kenner L, Florin L, Hummerich L, Mehic D, et al. Psoriasis-like skin disease and arthritis caused by inducible epidermal deletion of Jun proteins. Nature 2005;437:369-75.

68. Zenz R, Wagner EF. Jun signalling in the epidermis: from developmental defects to psoriasis and skin tumors. Int $\mathrm{J}$ Biochem Cell Biol 2006;38:1043-9.

69. Heilborn JD, Nilsson MF, Kratz G, Weber G, Sørensen O, Borregaard N, et al. The cathelicidin anti-microbial peptide LL37 is involved in re-epithelialization of human skin wounds and is lacking in chronic ulcer epithelium. $\mathrm{J}$ Invest Dermatol 2003;120:379-89.

70. Bhora FY, Dunkin BJ, Batzri S, Aly HM, Bass BL, Sidawy $A N$, et al. Effect of growth factors on cell proliferation and epithelialization in human skin. J Surg Res 1995;59:236-44.

71. Lee CW, Lin ZC, Hu SC, Chiang YC, Hsu LF, Lin YC, et al. Urban particulate matter down-regulates filaggrin via COX2 expression/PGE2 production leading to skin barrier dysfunction. Sci Rep 2016;6:27995.

72. Schikowski T, Hüls A. Air pollution and skin aging. Curr Environ Health Rep 2020;7:58-64.

73. Ahn K. The role of air pollutants in atopic dermatitis. J Allergy Clin Immunol 2014;134:993-9; discussion 1000.

74. Kim JH, Son JW, Kim J, Kim MG, Jeong SH, Park TJ, et al. Particulate matter $(\mathrm{PM})_{2.5}$ affects keratinocytes via endoplasmic reticulum (ER) stress-mediated suppression of apoptosis. Mol Cell Toxicol 2020;16:129-37.

75. Box NF, Terzian T. The role of p53 in pigmentation, tanning and melanoma. Pigment Cell Melanoma Res 2008;21:525-33.

76. Bhang SH, Sun AY, Yang HS, Rhim T, Kim DI, Kim BS. Skin regeneration with fibroblast growth factor 2 released from heparin-conjugated fibrin. Biotechnol Lett 2011;33:845-51.

77. Purwar R, Wittmann M, Zwirner J, Oppermann M, Kracht $M$, Dittrich-Breiholz $\mathrm{O}$, et al. Induction of C3 and CCL2 by C3a in keratinocytes: a novel autocrine amplification loop of inflammatory skin reactions. J Immunol 2006;177:4444-50.

78. Matsunaga T, Katayama I, Yokozeki H, Nishioka K. ICAM-1 expression on keratinocytes in mechanically-injured skin of a patient with atopic dermatitis. J Dermatol Sci 1996;12:219-26. 